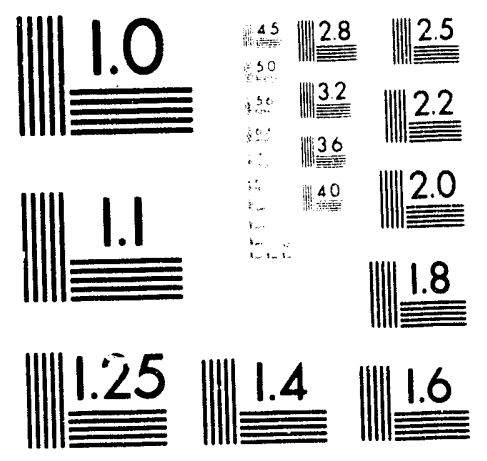



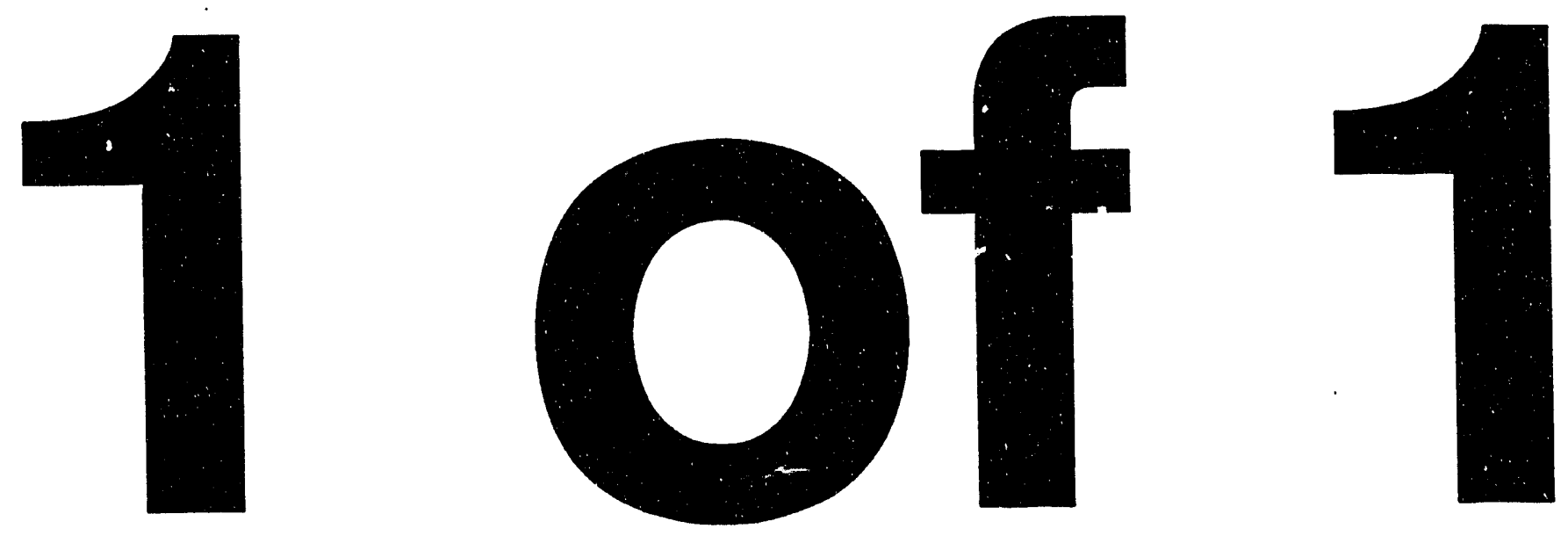


\section{Rearrangement of RAG-1 Recombinase Gene in Radiation-Sensitive "Wasted" Mice}

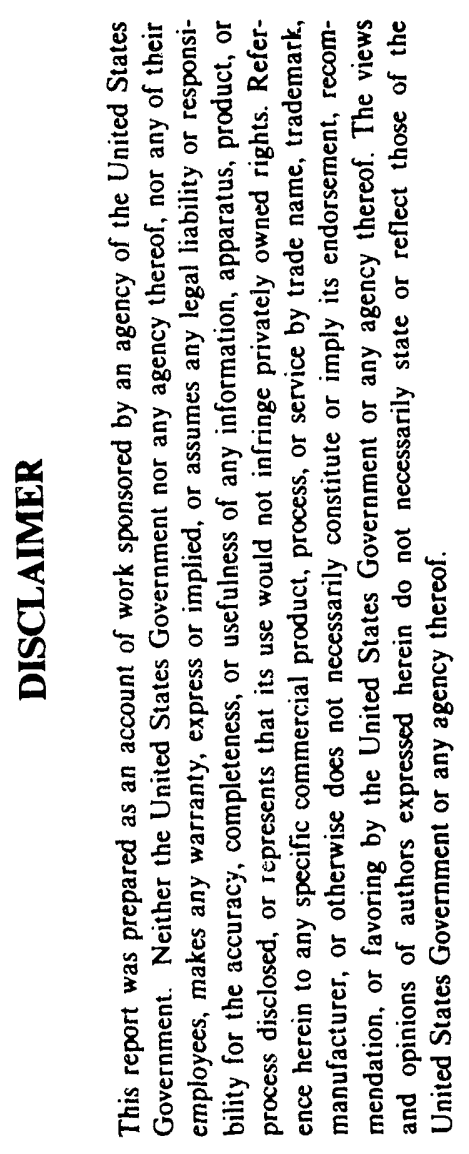

Gayle E. Woloschak, ${ }^{1,2}$ Claudia R. Libertin, ${ }^{3}$ Paul Weaver, ${ }^{2}$ Mark Churchill ${ }^{1}$ and Chin-Mei Chang-Liu ${ }^{1}$

'Center for Mechanistic Biology and Biotechnology Argonne National Laboratory 9700 S. Cass Avenue Argonne, IL 60439-4833

${ }^{1}$ Department of Pathology and ${ }^{2}$ Department of Medicine Loyola University of Chicago 2160 South First Avenue Maywood, IL 60153

Running Title: RAG-1 rearrangement in wasted mice 
Abstract-Mice recessive for the autosomal gene "wasted" (wst) display a disease pattern which includes increased sensitivity to the killing effects of ionizing radiation, immunodeficiency, and neurologic dysfunction. The recent cloning and characterization of recombinase genes (RAG-1/RAG-2) expressed in lymphoid and possibly central nervous system tissues prompted us to examine expression of these genes in DNA repairdeficient/immunodeficient wasted mice. Our results revealed expression of RAG-1 mRNA in spinal cord (but not brain) of control mice; no expression of RAG-1 mRNA was detected in spinal cord or brain from wst/wst mice or their normal littermates (wst/ mice). In thymus tissue, a small RAG-1 transcript $(1.0 \mathrm{~kb})$ was detected in wst/wst mice that was not evident in thymus from control mice. In wst $/$ mice, a two-fold increase in RAG-1 mRNA was evident in thymus tissue. RAG-2 mRNA could only be detected in thymus tissue from wst. and not from wst/wst or parental control $\mathrm{BCF}_{1}$ mice. Southern blots revealed a rearrangement/deletion within the RAG-1 gene of affected wasted mice, not evident in known strain-specific parental or littermate controls. These results support the idea that the RAG-1 gene may map at or near the locus for the wasted mutation. In addition, they suggest the importance of recombinase function in normal immune and central nervous system development as well as the potential contribution of this gene family to the normal repair of radiation-induced DNA damage. 


\section{INTRODUCTION}

Initial reports describing the wasted mouse mutation defined an autosomal recessive defect that resulted in premature death (by 28 days of age), neurologic dysfunction, and increased sensitivity of lymphocytes to damage by ionizing radiation as measured by chromosome breaks (Schultz et al. 1982). This strain was considered a model for the human disease ataxia telangiectasia, although later reports documented that not all features of the mouse disorder were similar to those found in the human disease (Goldwitz et al. 1985; Inoue et al. 1986b; Woloschak et al. 1987). The neurologic dysfunction was found to involve a degenerative loss of anterior motor neurons of the cerebellar cortex and spinal cord (Woloschak et al. 1987; Lutsep and Rodriguez 1989). The DNA repair abnormality involved both an increased spontaneous incidence of chromosomal damage in bone marrow cells (Schultz et al. 1982) and increased sensitivity of lymphocytes to the killing effects of ionizing (but not ultraviolet) radiation (Padilla et al. 1990; Inoue et al. 1986a; Nordeen et al. 1984; Tezuka et al. 1986). Numerous reports have documented immunodeficiency in wasted mice, particularly deficiency in IgA expression and immune responses at mucosal sites (Woloschak et al. 1987, 1988; Kaiserlian et al. 1985, 1986). The mutation has been mapped to chromosome 2 of the mouse through breeding experiments (Beechey and Searle 1982), but the affected genes have not been identified.

In recent work, Oettinger et al. (1990) identified RAG-1 and RAG-2 recombinases that synergistically activate V(D)J recombination in both B- and T-lymphocytes. Chun et al. (1991) determined that the RAG-1 gene is expressed in both lymphoid and central nervous 
system (CNS) tissue. The precise functions of these genes are still undetermined, although their roles both in gene recombination and in gene conversion have been suggested (Oettinger et al. 1990; Chun et al. 1991; Carlson et al. 1991). In previous work, we hypothesized that the entire disease syndrome of v'asted mice could be explained by the absence of a recombinase function required for (a) double-stranded DNA repair, (b) lymphocyte immunoglobulin and T-cell receptor rearrangement, and (c) rearrangement of an as-yet-unidentified gene in the CNS (Woloschak et al. 1987; Padilla et al. 1990). The identification of RAG-1 as a lymphoid- and CNS-specific recombinase suggested that this gene might be involved in the disease pattern of wasted mice.

\section{MATERIALS AND METHODS}

\section{Mice}

All experiments reported here used wst/wst mice bred from $\underline{\text { wst }}+$ breeders obtained from the Jackson Laboratory (Bar Harbor, ME). All wst/wst mice expressed neurologic symptoms (whole body tremors, failure to gain weight, inability to navigate an inclined plane) at 21-22 days of age and were sacrificed at days 25-28 of age. Littermate controls (noted as $\underline{\mathrm{WSt}} \cdot$ in this manuscript) and $\mathrm{BCF}_{1}$ parental controls were age- and sex-matched for all experiments reported here. The "wasted" mutation arose in HRS/J mice but has been bred into the $\mathrm{BCF}_{1}$ background. Known $\underline{\mathrm{wt}} \mathrm{t}+$ mice (which can only be identified by breeding and therefore cannot be age-matched with ws (wst mice) were used for RAG-1 DNA Southern blot experiments. 


\section{Hybridizations}

Northern blots and Southern blots were done as outlined in the figure legends and as previously described (Woloschak et al. 1986, 1990). RNA was separated by usir..g formaldehyde agarose gel electrophoresis as described previously (Woloschak et al. 1986). In brief, RNA samples (10 $\mu \mathrm{g} / \mathrm{sample}$ ) were denatured in $50 \%$ formamide, $1.9 \mathrm{M}$ formaldehyde, $0.2 \mathrm{M}$ MOPS, $50 \mathrm{mM}$ sodium acetate, $1 \mathrm{mM} \mathrm{Na} \mathrm{N}_{2} \mathrm{EDTA}, \mathrm{pH} 7.5$, for $15 \mathrm{~min}$ at $55^{\circ} \mathrm{C}$, then separated on $1.2 \%$ agarose gels in 0.2 MOPS, $50 \mathrm{mM}$ sodium acetate, $1 \mathrm{mM} \mathrm{Na}$ EDTA, 2.2 $M$ formaldehyde. Northern transfers were performed as described (Woloschak et al. 1986). Blots were hybridized to ${ }^{32} \mathrm{P}$-labeled cDNA probes. Hybridization conditions were $50 \%$ deionized formamide, $0.75 \mathrm{M} \mathrm{NaCl}, 75 \mathrm{mM}$ sodium citrate, $25-50 \mathrm{mM}$ sodium phosphate, $\mathrm{pH}$ $6.5,0.2 \%$ SDS, $0.2 \%$ bovine serum albumin, $0.2 \%$ ficoll, $0.2 \%$ polyvinylpyrrolidone, and 50 $\mu \mathrm{g} / \mathrm{mL}$ sonicated denatured herring sperm DNA at $43{ }^{\circ} \mathrm{C}$. Prior to hybridization, all labeled probes were heat-denatured at $90^{\circ} \mathrm{C}$ for $5 \mathrm{~min}$. After hybridization, nonspecific binding was reduced by washing the hybridized blots 3 times for $1 \mathrm{~h}$ each in $1.5 \mathrm{mM}$ sodium citrate ( $\mathrm{pH}$ 7.4), $15 \mathrm{mM} \mathrm{NaCl}, 50 \mu \mathrm{g} / \mathrm{mL}$ herring sperm DNA (sonicated, denatured), and $0.1 \%$ SDS. The blots were then dried and exposed to $x$-ray film at $-20^{\circ} \mathrm{C}$. In some experiments, the same blot was washed and hybridized successively to several different probes. Each probe was eluted by washing for $24 \mathrm{~h}$ in distilled deionized water at $43^{\circ} \mathrm{C}$, and blots were checked (for total removal of the labeled probes) by $24-\mathrm{h}$ exposure to $\mathrm{x}$-ray film.

Southern blots were performed as described (Woloschak et al. 1986). In brief, DNA was purified from these cells by extraction in Tris-buffered phenol, precipitation from ethanol, and digestion with $10 \mu \mathrm{g} / \mathrm{ml}$ pancreatic ribonuclease followed by digestion with $50 \mu \mathrm{g} / \mathrm{ml}$ 
proteinase $\mathrm{K}$. Liver-derived DNA from wst/wst mice, wst/ mice, and $\mathrm{BCF}_{1}, \mathrm{BALB} / \mathrm{C}$ and C57BL/6 strain-specific controls was digested with restriction enzyme following manufacturer's specifications and subjected to $1.2 \%$ agarose gel electrophoresis in E buffer (40 mM Tris-acetate, $2 \mathrm{mM} \mathrm{Na} 2$ EDTA, $\mathrm{pH} 7.7$ ). In all gels, standard molecular weight markers (HindIII digest of phage $\lambda$ ) were run and DNA was visualized by staining in ethidium bromide. After depurination for $10 \mathrm{~min}$ in $0.25 \mathrm{M}$ HCI, DNA was denatured in the gel by incubating for $30 \mathrm{~min}$ at room temperature in $0.6 \mathrm{M} \mathrm{NaOH}, 1.5 \mathrm{M} \mathrm{NaCl}$ followed by $30 \mathrm{~min}$ in $1.0 \mathrm{M}$ Tris- $\mathrm{HCl}(\mathrm{pH} 8.0), 1.5 \mathrm{M} \mathrm{NaCl}$ at room temperature. DNA from the gel was then transferred to an MSI neutral nylon membrane in $10 \times \mathrm{SSC}(150 \mathrm{mM}$ sodium citrate, $\mathrm{pH}$ $7.4,1.5 \mathrm{M} \mathrm{NaCl}$ ) for $18 \mathrm{~h}$ at room temperature. Blot-bound DNA was hybridized to the heatdenatured ${ }^{32} \mathrm{P}$-labeled RAG-1 DNA probe in Southern hybridization buffer $(2.5 \mu \mathrm{g} / \mathrm{ml}$ poly(A), $50 \mu \mathrm{g} / \mathrm{ml}$ herring sperm DNA, $0.1 \%$ SDS, $0.2 \%$ ficoll, $0.2 \%$ bovine serum albumin, $0.2 \%$ polyvinylpyrrolidone, $6 \times \mathrm{SSC}$ ) at $65{ }^{\circ} \mathrm{C}$ for $18 \mathrm{~h}$. The blot was then washed 3 times at $65^{\circ} \mathrm{C}$ for $1 \mathrm{~h}$ each in $0.5 \times \mathrm{SSC}$. Blots were autoradiographed at $-70^{\circ} \mathrm{C}$ to detect genespecific sequences.

cDNA clones

We gratefully acknowledge Dr. D. Baltimore's (The Rockefeller University) generous gift of RAG-1 (M6) and RAG-2 (MR2-1) DNA, Dr. David McKean (Mayo Clinic, Rochester, MN) who provided murine IL2 cDNA, Dr. C.Veneziale (Mayo Clinic, Rochester, MN) who provided $\alpha$-tutulin cDNA. 


\section{RESULTS AND DISCUSSION}

Experiments were designed to examine RAG-1 and RAG-2 expression in lymphoid and CNS tissues of wasted mice as well as in tissues from littermate and parental controls. Figure 1, Northern blots for RAG-1 and RAG-2 mRNA expression, documents that thymus tissue of $\underline{\text { wSt }} / \underline{\text { wst }}$ mice expressed a small RAG-1 transcript $(1 \mathrm{~Kb})$ while age-matched parental and littermate controls expressed significant amounts of the normal sized mRNA in thymus. In addition, wst $/$ mice expressed at least two-fold more RAG-1 mRNA than parental controls $\left(B C F_{1}\right.$ mice) or affected wst/wst littermates. Low levels of RAG-1 miRNA were found in spleen of $\mathrm{BCF}_{1}$ and $\underline{\mathrm{wst}} \cdot$ mice, but RAG-1 transcripts were undetected in spleen from wst/wst mice (Fig.1). In addition, RAG-1 mRNA was not detected in brain of any mouse strains examined $\left(\mathrm{BCF}_{1}, \underline{\mathrm{wst}} \cdot\right.$ or $\left.\underline{\mathrm{wst}} / \underline{\mathrm{wst}}\right)$, but was evident in high abundance in spinal cord of $\mathrm{BCF}_{1}$ mice, but not in spinal cord from wst. or wst/wst mice (Fig. 1). RAG-2 mRNA was not detected in spinal cord or brain of any mouse strains examined (not shown), but was evident in thymus of wst . mice (Fig. 1). Re-hybridization of these blots to IL2 (for thymus and spleen) and $\alpha$-tubulin (for brain and spinal cord) revealed equal amounts of intact mRNA on each blot (not shown). Similarly, expression of RAG-2 mRNA was not detected in thymus tissue derived from wst wst mice, but was expressed at elevated levels in wst $/$ thymus (Fig. 1D). Thymus from 28-day old wasted mice is involuted and has fewer cells than agematched controls (Kaiserlian et al. 1985, 1986; Woloschak 1988). Northern blots were based on $\mu \mathrm{g}$ quantities of RNA loaded rather than tissue weight.

Southern blots were performed to determine the status of the RAG-1 gene in wst wst mice relative to controls. Figure 2 presents the results of such a Southern blot done with the 
RAG-1 clone using liver DNA derived from wst wst mice, wst $/$ littermates, and $\mathrm{BCF}_{1}$ controls as well as $\mathrm{BAJ} / \mathrm{B} / \mathrm{c}$ and $\mathrm{C} 57 \mathrm{BL} / 6$ strain controls. In each digest of liver DNA, novel or altered bands evident in ws evident in controls were also detected in DNA from wst/wst mice, suggesting that wasted mice do not have a total deletion of the RAG-1 gene. The sizes of RAG-1 fragments in control mice for all digests were similar to those reported previously (Oettinger 1990). It is also interesting that the wst $\cdot$ mouse used here expresses some of the abnormal bands evident in the wst/wst affected littermates, suggesting a heterozygosity in this wst $\cdot$ mouse at this locus. In contrast to RAG-1, hybridization to RAG-2 clone, $\beta$-actin clone (generously provided by Dr. Larry Kedes, Stanford Univ.), and chromosome 2-specific c-ets clone (provided by American Type Culture Collection) revealed identical patterns of hybridization among wst/wst, wst/, and $\mathrm{BCF}_{1}$ DNA samples (not shown).

The results of a RAG-1 gene alteration in wst/wst mice suggest that the RAG-1 gene may map at or near the wst locus. While we and others have reported low expression of several genes in wasted mice relative to controls (Woloschak 1987; Inoue 1986), no reports have established an associated alteration in any gene at the DNA level. Because the RAG-1 gene shows such an alteration, we suspect that the primary genetic defect of wasted mice may be associated with the RAG-1 deficiency. RAG-2 gene appears to be intact based on Southern-blot analysis; however, we have failed to detect expression which may be the result of rearrangement into a non-expressed area of the genome. Experiments are underway to test this. 
Several reports have suggested that $\underline{\text { scid }}$ mice are defective in RAG-1 expression (Oettinger et al. 1990; Chun et al. 1991; Carlson 1991). The total immunoglobulin/T-cell receptor immunodeficiency of scid mice (which express faulty V-D-J joining) is quite distinct from the abnormalities of wasted mice. The same genes may be involved in both defects, but with a combination of some other contributing genetic lesion resulting in the scid manifestation of altered immune disorders. On the other hand, the genetic lesion in scid mice may not involve the recombinase per se, but rather a protein (working in association with the recombinase) that is required for immunoglobulin and $\mathrm{T}$-cell receptor gene rearrangement but is not involved in CNS function. The similarities between the wasted syndrome and ataxia telangiectasia in humans will provide for interesting future analyses of RAG-1 involvement in the human disorder.

For the $\underline{\text { wst }} \cdot$ mice used in these experiments, we have demonstrated elevated RAG-1 and RAG-2 expression in the thymus, perhaps the result of over-compensation by the one copy of the normal gene for the production of an aberrant RAG-1 transcript from the aitered allele. This is further supported by the faint hint of an altered transcript $(1.0 \mathrm{~kb})$ in wst/. thymus (Fig. 1A) and the presence of some altered RAG-1 DNA fragments in wst/. mice on Southern blot (Fig. 2).

The demonstration that mice expressing the wasted phenotype (i.e., sensitivity to ionizing radiation, mucosal immunodeficiency, and neurologic dysfunction) express abnormal RAG-1 transcript suggests an important role for the this gene in normal development, since wst/wst mice do not live beyond 32 days of age (1). The radiation sensitivity profiles of wasted mice implicate RAG-1 as a mammalian DNA repair enzyme required for complete 
repair of damage induced by ionizing radiation (double-strand breaks?), since failure to express the gene in this mouse system results in an extreme sensitivity to the killing effects of gamma rays. The fact that other investigators have shown variable results in expression of RAG-1 mRNA in CNS tissue (Oettinger et al. 1990; Chun et al. 1991) could be attributed to the fact that expression is specific for spinal cord; the amount of contamination of brain tissue with spinal cord could vary from one preparation to the other. The importance of RAG-1 expression in spinal cord and for CNS function suggests the presence of some as-yetunidentified gene recombination event which is essential for maintenance and function of anterior motor neuron cells in the mouse cerebellar cortex and spinal cord. It is interesting that anterior motor neuron cells have been reported to be the most radiation-sensitive cells in mouse CNS tissues (Moss and Lewkowicz 1985).

The immunodeficiency of wasted mice is specifically directed toward defective IgAmediated mucosal immunity, potentially relating RAG-1 function with IgA responses. Several reports have suggested that $\operatorname{IgA}$ responses require multiple rounds of DNA synthesis and especially frequent recombination events in mice (Woloschak and Tomasi 1983; Gearhart and Cebra 1991). It has been hypothesized in the gut that the high antigen concentration is required to drive this IgA expression (Gearhart and Cebra 1982). Defective IgA expression in wasted mice could be associated with a failure of normal recombination in gut-associated mucosal lymphocytes needed to drive an $\operatorname{IgA}$ response. This would explain the $\operatorname{IgA}$ deficiency at mucosal sites, a prominent feature of the wasted mouse immunodeficiency. On the other hand, a recent report by George and Cebra (1991) has shown that a single B-cell can be driven to IgA expression in the absence of cell division, showing that at least some 
IgA-producing cells do not require prior cell division. Studies of the wasted mouse model may further resolve this issue.

Finally, several recent reports (Mombaerts et al. 1992; Shinkai et al. 1992) have analyzed mice genetically altered at either the RAG-1 (Mombaerts et al. 1992) or the RAG-2 (Shinkai et al. 1992) locus. These mice share some, but not all, features with wasted mice, especially the CNS abnormality which is not evident in either RAG-1 or RAG-2 mutated mice. We believe these differences could be attributed to several possible explanations: (1) wst/wst mice may produce some functional RAG-1 product, even through the gene is altered. (2) wst/wst mice may express a rearrangement of RAG-1 gene such that another gene (into which it is rearranged) is altered. (3) wst/wst mice show abnormalities in expression of RAG-1 and RAG-2, while the genetically engineering mutant mice have only one or the other gene affected. Furiher experiments will be required to examine these possibilities.

Acknowledgements - The authors wish to thank Kay Bexson for preparing this manuscript and Drs. Carol Giometti, Frank Collart, and Marianne Schiffer for critical review prior to submission.

This work was supported by U. S. Department of Energy, Office of Health and Enviroumental Research, under Contract W-31-109-ENG-38. 


\section{REFERENCES}

Beechey C. V. and Searle A. G. (1982) Mouse Newslett., 70, 78.

Carlson L. M., Oettinger M. A., Schaltz D. G., Mesteller E. L., Hurley E. A., McCormack W. T., Baltimore D. and Thompson C. B. (1991) Selective expression of RAG-2 in chicken B cells undergoing immunoglobulin gene conversion. Cell, 64, 201-208.

Chun J. J. M., Schatz D. G., Oettinger M. A., Jaenisch R. and Baltimore D. (1991) The recombination activating gene-1 (RAG-1) transcript is present in the murine central ne rous system. Cell, 64, 189-200.

Gearhart P. J. and Cebra J. J. (1981) Most B cells that have switched surface immunoglobulin isotypes generate clones of cells that do not secrete IgM. J. Immunol., 127, $1030-1037$.

George A. and Cebra J. J. (1991) Responses of single genminal-center B cells in T-celldependent microculture. Proc. Natl. Acad. Sci. USA 88, 11-15.

Goldowitz D., Shipman P. M., Porter J. F. and Schmidt R. R. (1985) Longiudinal assessment of immunologic abnormalities of mice with the autosomal recessive mutation, "wasted". J. Immunol., 135, 1806-1812.

Inoue T. K., Aikawa K., Tezuke H., Kada T. and Shultz. L. (1986a) Effect of DNA damaging agents on isolated spleen cells from the mouse mutant "wasted," a putative animal model for ataxia telangiectasia. Cancer Res., 46, 3979-3982.

Inoue T., Tezuke H., Kada T., Aikawa K. and Shultz L. D. (1986b) The mouse mutant "wrsted," an animal model for ataxia-telangiectasia. In Antimutagenesis and 
Anticarcinogenesis Mechanisms (Edited by Shankel D. M., Hartman P. E., Kada T. and Hollaender A.), pp. 323-335. Plenum Publishing Corporation, New York.

Kaiserlian D., Delacroix D. and Bach J. F. (1985) The wasted mutant mouse. I. An animal model of secretory IgA deficiency with normal serum IgA. J. Immunol., 135, $116-1131$.

Kaiserlian D., Savino W., Uriel J., Hassid J., Dardenne M. and Bach J. F. (1986) Immunological abnormalities in a mouse described as a model of ataxia-telangiectasia. Clin. Exp. Immunol., 63, 562-569.

Lutsep H. K. and Rodriguez M. (1989) Ultrastructural morphometric, and immunocytochemical study of anterior horn cells in mice with "wasted" mutation. $J$. Neuropathol. Exp. Neurol., 48, 519-533.

Mombaerts P., Iacomini J., Johnson R. S., Herrup K., Tonegawa S. and Papaioannou V. E. (1992) RAG-1 deficient mice have no mature B and T lymphocytes. Cell, 68, 869-877.

Moss T. H. and Lewkowicz S. J. (1985) Effect of ionizing radiation on the axon reaction of mouse anterior horn motor neurons. A histological and immunocytochemical study using a monoclonal antibody to neurofilament protein, J. Neurol. Sci., 67, 1-14.

Nordeen S. K., Schaefer V. G., Edgell M. H., Hutchinson III C. A., Schultz L. D. and Swift M. (1984) Evaluations of wasted mouse fibroblast and SV-40 transformed human fibroblasts and models of ataxia telangiectasis in vitro. Mutat. Res., 140, 219-222.

Oettinger M. A., Schatz D. G., Gorka C. and Baltimore D. (1990) RAG-1 and RAG-2, adjacent genes that synergistically activate V(D)J recombination. Science, 248, 1517-1523. 
Padilla M., Libertin C., Krco C. and Woloschak G. E. (1990) Radiation sensitivity of Tlymphocytes from immunodeficient "wasted" mice. Cell. Immunol., 130, 186-194.

Schultz L. D., Sweet H. O., Davisson M. J. and Conan D. R. (1982) "Wasted," a new mutant of the mouse with abnormalities characteristic of ataxia telangiectasia. Nature, 297, $402-405$.

Shinkai Y., Rathbun G., Lam K-P., Oltz E. M., Stewart V., Mendelsohn M., Charron J., Datta M., Young F., Stall A. M. and Alt F. W. (1992) RAG-2 deficient mice lack mature lymphocytes owing to inability to initiate V(D)J rearrangement. Cell, 68, 855-867.

Tezuka H., Inoue T., Noguti T., Kada T. and Shultz L. D. (1986) Evaluation of the mouse mutant "wasted" as an animal model for ataxia telangiectasia. I. Age-dependent and tissuc-specific effects. Mutat. Res., 161, 83-90.

Woloschak G. E., Dewald G., Bahn R. S., Kyle R. A., Greipp P. R. and Ash R. C. (1986) Amplification of RNA and DNA specific for erb B in unbalanced 1;7 chromosomal translocation in myelodysplastic syndrome. J. of Cellular Biochem., 32(1), 23-34.

Woloschak G. E., Krco C. J. and Rodriguez M. (1988) Influences of the microenvironment on B-cell responses of wasted mice: comparison of Peyer's patches and mesenteric lymph nodes. Regional Immunol., 1, 163-171.

Woloschak G. E., Liu C.-M. and Shearin-Jones P. (1990) Regulation of protein kinase C by ionizing radiation. Cancer Res., 50, 3963-3967.

Woloschak G. E., Rodriguez M. and Krco C. J. (1987) Characterization of immunologic and neuropathologic abnormalities in "wasted" mice. J. Immunol., 138, 2493-2499. 
Woloschak G. E. and Tomasi T. B. (1983) Immunology and molecular biology of the secretory IgA system of the gut. CRC Critical Reviews in Immunol. 4, 1-18. 


\section{FIGURE LEGENDS}

Figure 1. Northern blot hybridization of (A) thymus poly(A)+ RNA to RAG-SV1, (B) spleen poly(A)+ RNA to RAG-1, (C) CNA derived poly(A)+ RNA to RAG-1, (D) thymus poly(A)+ RNA to RAG-2.

Figure 2. Southern blot of liver-derived DNA to RAG-1 clone. Liver DNA from wst/wst (w/w), wst/ $\cdot(w / \cdot), B C F_{1}, B A L B / C$ and $C 57 B L / 6$ mice was digested with the indicated enzyme prior to electrophoresis, blotting and hybridization to RAG-1 cDNA clone. 


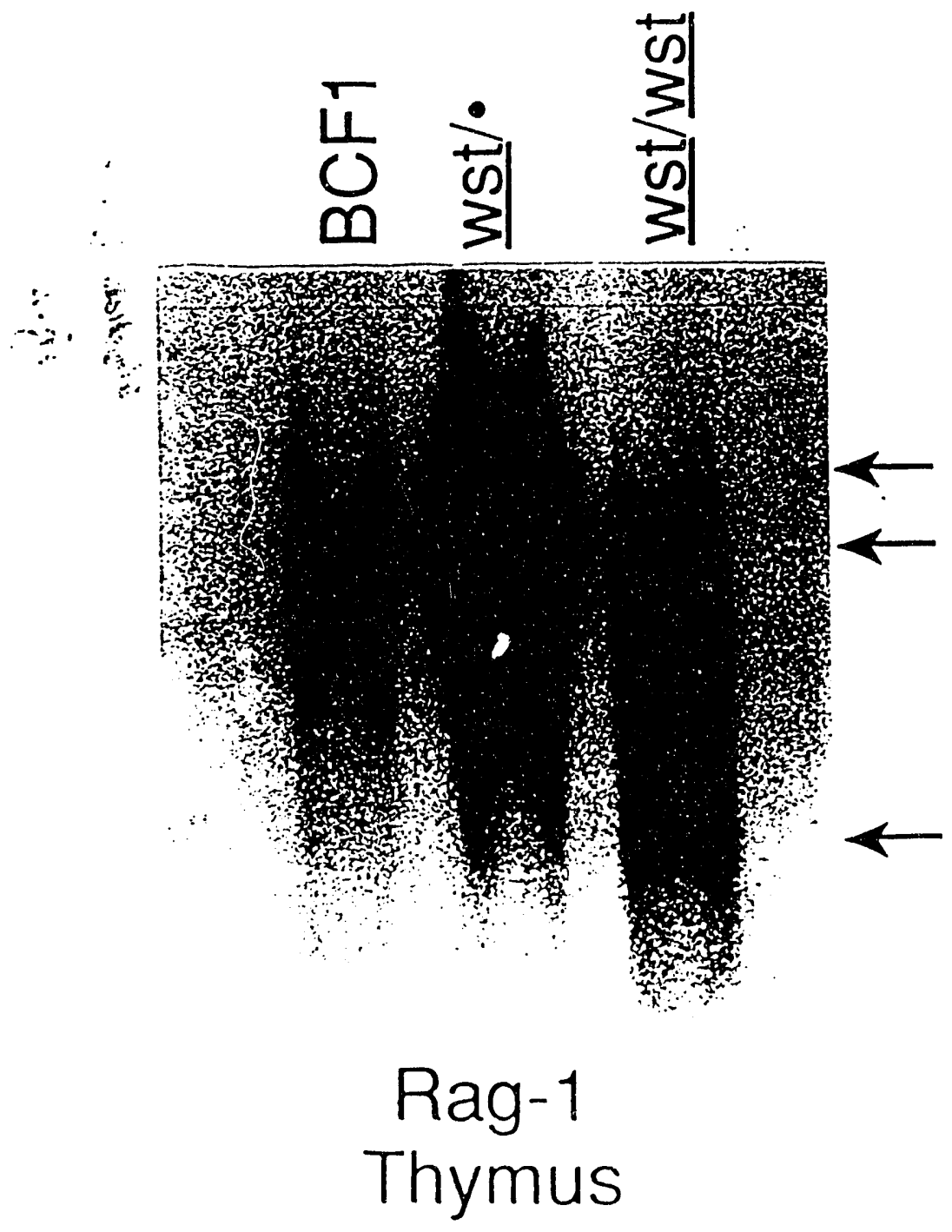

Fig I A 


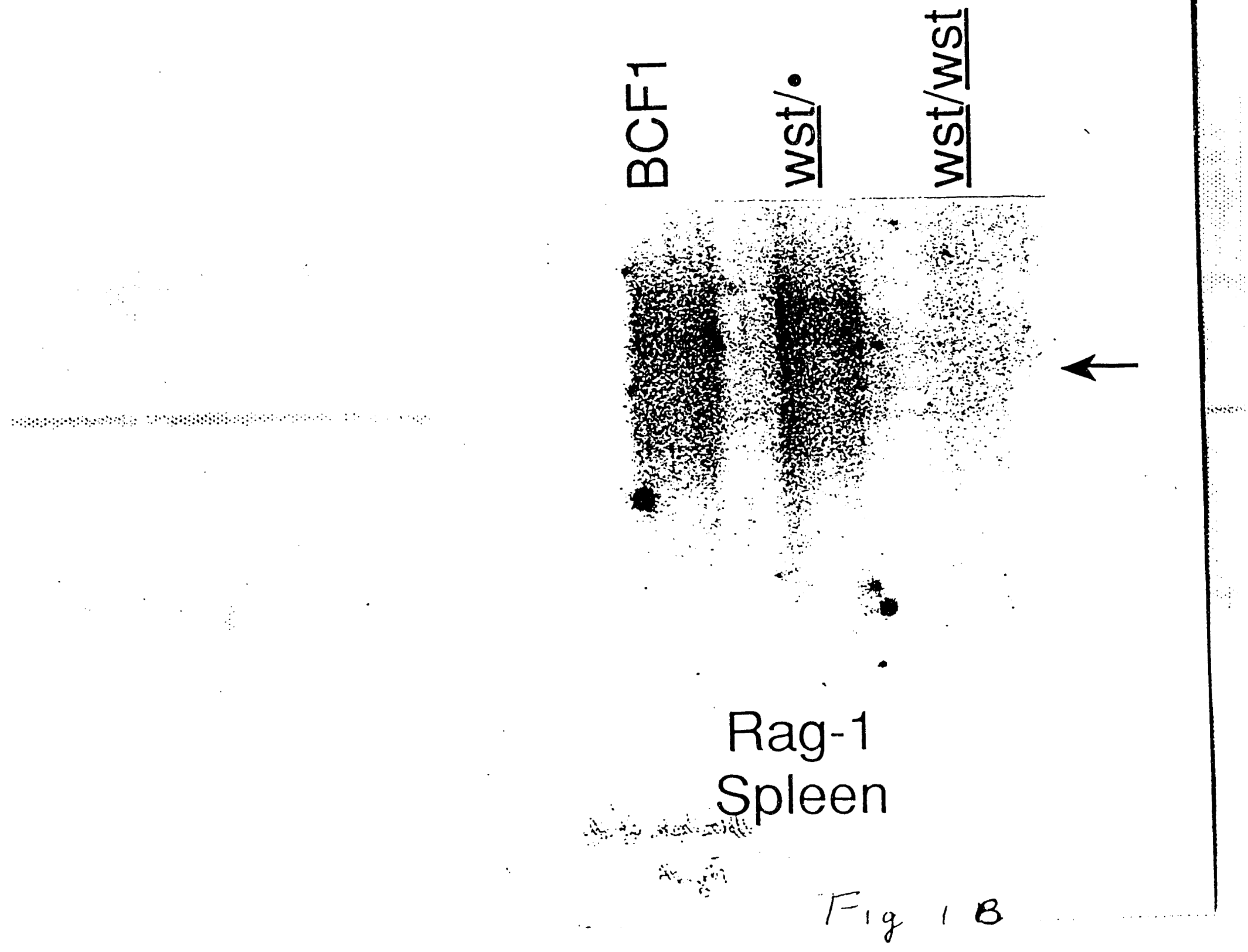




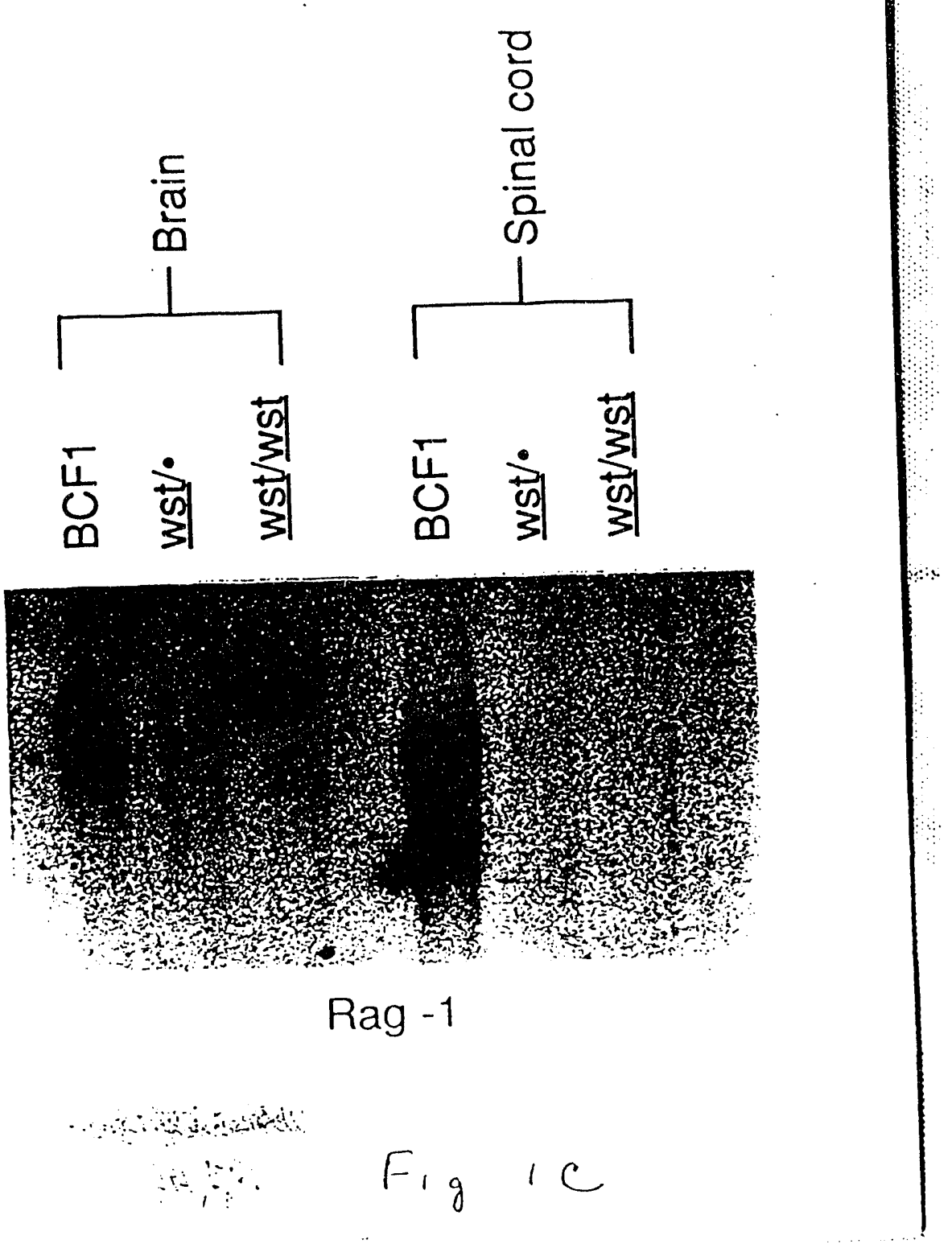




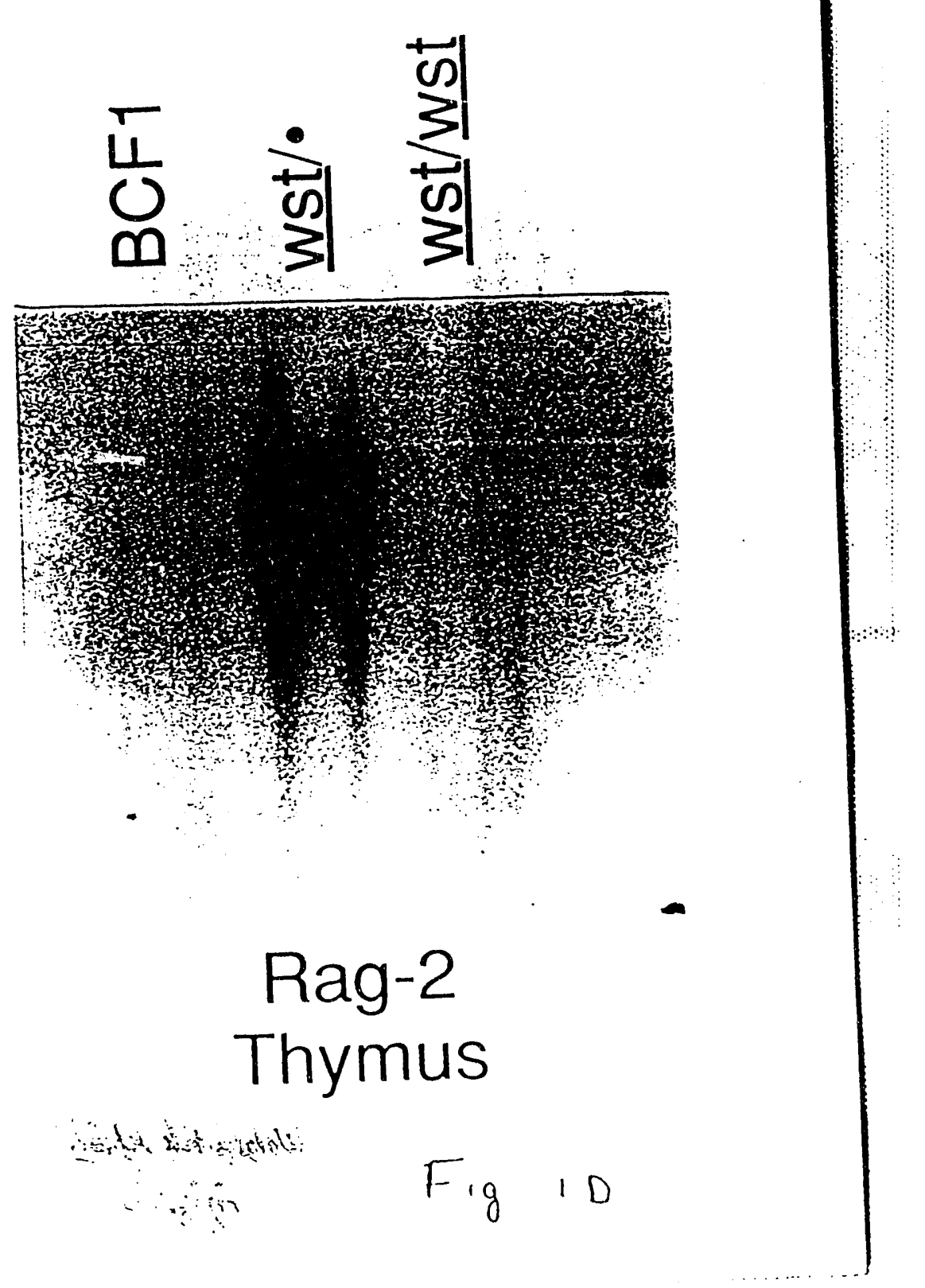




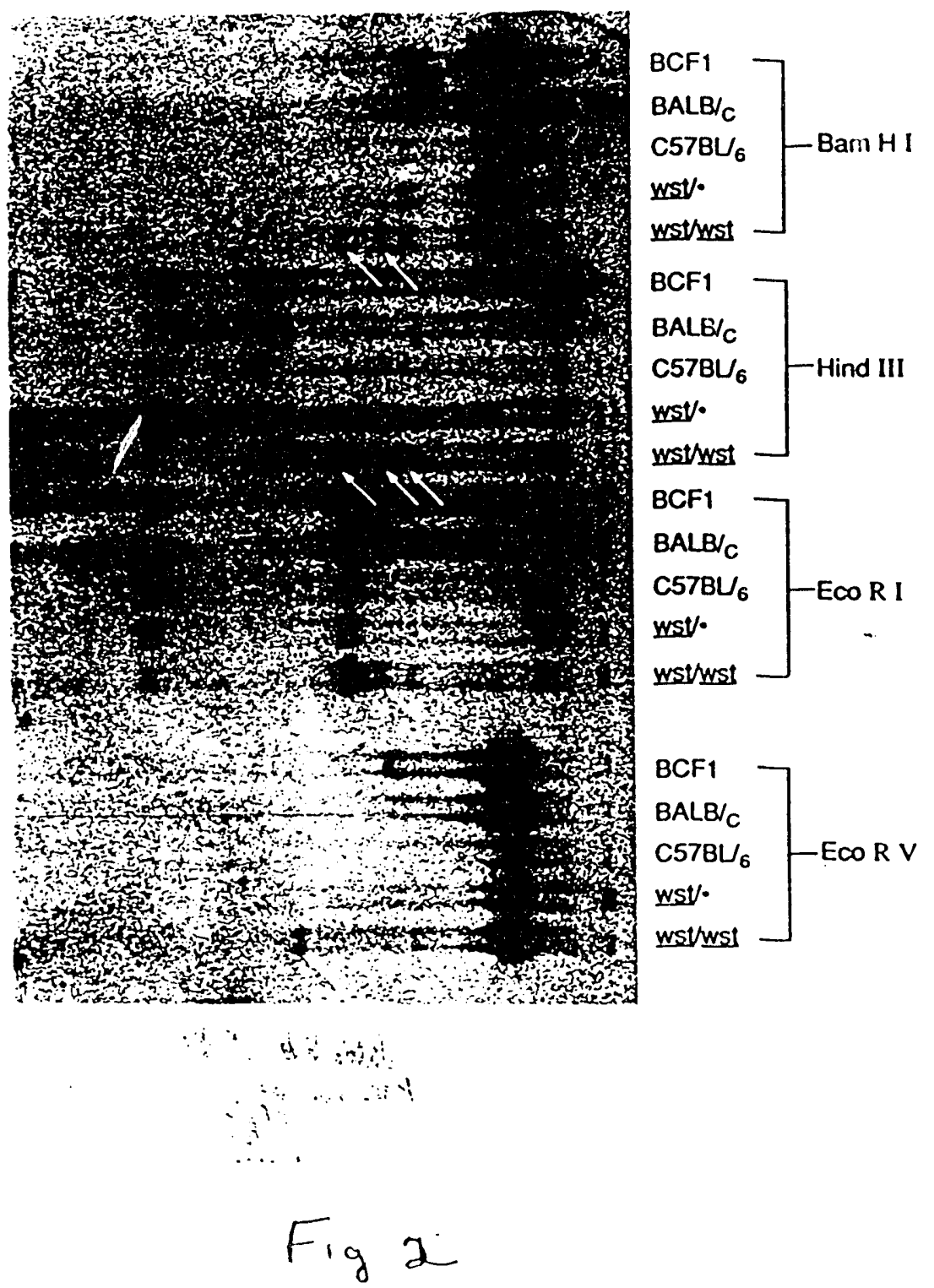



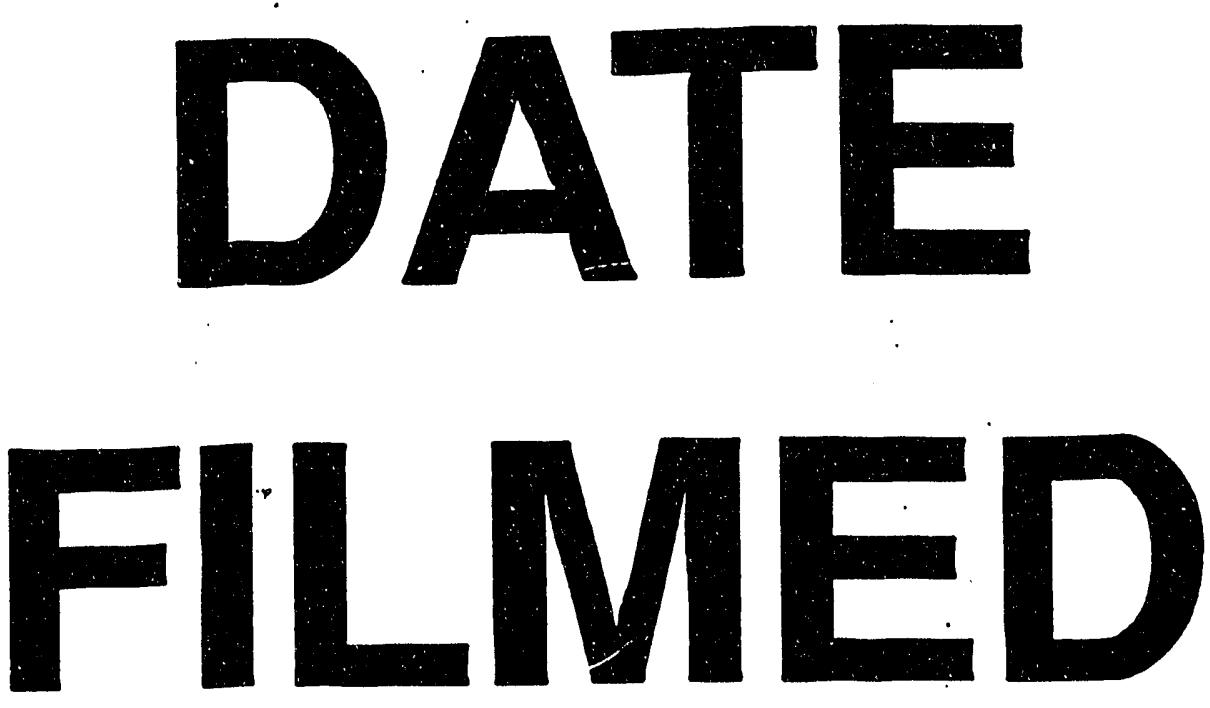

$12 / 3 / 93$
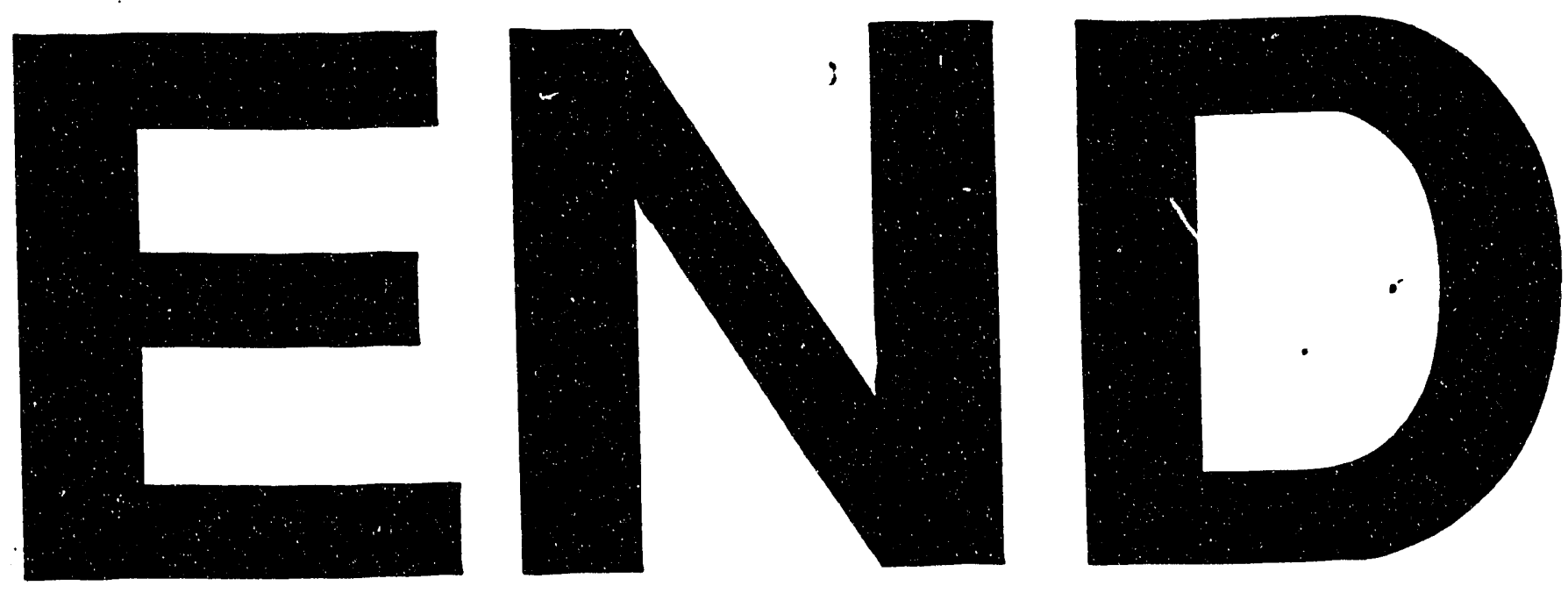
